\title{
Integrating preparation for international exams into foreign language education curriculum at university
}

\author{
Dina Vladimirovna Fedorova ${ }^{1 *}$, Svetlana Alexandrovna Pashneva ${ }^{2}$, Victoria Viktorovna \\ Klimentyeva ${ }^{1}$, Dmitry Dmitrievich Klimentyev ${ }^{1}$, and Anna Valerievna Umerenkova ${ }^{1}$ \\ ${ }^{1}$ Kursk State University, Department of Language Theory and Methods of Teaching Foreign \\ Languages, Kursk, Russia \\ ${ }^{2}$ Kursk State University, Department of Translation and Intercultural Communication, Kursk, Russia
}

\begin{abstract}
In order to increase competitiveness of graduates not only in our country, but abroad as well, the development of the higher education system in Russia requires qualitative changes in the content of language training of students who are to be capable of integration into the global multicultural community, academic mobility, independence and constant professional growth. In this regard, there arises a question whether the quality of students' knowledge, skills and abilities in the field of foreign language communication may comply with the requirements of international standards. The article reflects the results of theoretical research and practical experience in international exams preparation as part of foreign language instruction provided by the Foreign Languages Faculty of Kursk State University thus substantiating the hypothesis that it is possible to optimize the development of skills and abilities necessary to successfully pass international exams if the subject-related tasks and exercises are designed in their format and offered both for in-class and self-study activities. The purpose hereof is to explore feasibility of implementing effective preparation for international language exams in class without interference with the major curriculum. The scientific novelty of the research lies in the development and testing of a model of the educational trajectory leading to the formation of the competencies that meet international standards of foreign language education in graduates, majoring in languages. Having applied classical research methods analysis of publications and accumulated methodological experience, trial learning and observation - the authors came to the conclusion that the proposed approach is feasible and productive.
\end{abstract}

Keywords: language teaching, exams, higher education, quality of education, examination standards

\section{Introduction}

* Corresponding author: dinafedorova291@gmail.com 
At the present stage of social development, the problem of university graduates' competitiveness is becoming increasingly relevant. The requirements of the Federal State Educational Standard of Higher Education in the fields of training 45.03.02 Linguistics and 44.03.05 Pedagogical education list the competencies that will allow future linguists and foreign language teachers to carry out professional activities in the Russian and international labor market successfully. A special place among them is occupied by "the ability to carry out interlingual and intercultural interaction in oral and written forms both in the general and in the professional spheres of communication" [1].

However, today it is not enough to be able to communicate fluently in a foreign language, since in employment, preference is given to specialists who have a certificate of language proficiency according to the Common European Framework of Reference (CEFR). The importance of obtaining international certificates in a foreign language is evidenced by recent studies by a number of foreign scholars [2-6].

Unfortunately, the Federal State Educational Standard of Higher Education reflects only in general terms the requirements that the modern labor market imposes on linguiststranslators and teachers. It is no coincidence that the problem of preparing students for international language exams has recently attracted many researchers.

Such training can be carried out both in optional [7-11] and compulsory language classes as part of the major curriculum [12-17].

Based on the foregoing, it seems appropriate to integrate preparation for the Cambridge ESOL, IELTS or TOEFL exams into the major curriculum by including assignments of various formats in the educational process, which is the purpose of our study.

The research hypothesis can be formulated as follows: students' preparation for international exams at foreign languages faculties can be optimized by integrating it directly into language-related classes within the curriculum.

Since 2016, the proposed hypothesis has been tried and tested by the Foreign Languages Faculty of Kursk State University.

\section{Methods}

Research methods are determined by the above-mentioned features of preparation for exams of various forms at the Foreign Languages Faculty and include analysis of publications on the subject of research; pedagogical observation of students; testing, including pre-testing based on materials provided by Cambridge Assessment; analysis of official Cambridge ESOL test results; experimental training and analysis of its efficiency.

\section{Results}

The experimental work on the integration of preparation for international exams into the educational process was carried out in several stages. At the first stage from 2016 to 2017, the literature on research issues was studied, material was selected from authentic manuals of foreign publishing houses, which was later used to design a set of instructional material to develop language skills necessary to successfully pass the international exam. The educational and methodological support of the taught subjects was updated, test assignments for all types of control were drawn up.

At the second (pre-experimental) stage from 2018 to 2019, the designed materials were tested in a preliminary classroom experiment. Its results proved that preparation for exams within the syllabus is not an end in itself, but only a means of developing language competence for the following reasons. Firstly, the Federal State Educational Standard of Higher Education does not require graduates to hold an international language certificate. 
Secondly, it is not advisable to limit the process of developing students' foreign language competencies to doing exam-related tasks that resemble the format and reflect the content of international exams. Finally, the use of the exam format tasks alone can significantly reduce the quality of training [18]. Therefore, there should be three main areas of preparation for international language exams in various academic years of study at the Foreign Languages Faculty: 1) partial use of authentic teaching and test materials designed as an official exam preparation pack; 2) tailoring exam-related exercises based on authentic materials; 3) students' self-study.

Let us consider how language training is carried out in each area (using the example of Cambridge ESOL and IELTS assignments).

In the first area, $3^{\mathrm{d}}$ to $5^{\text {th }}$ year students are offered authentic exam-format tasks in language classes, which allows them to fully immerse in the English-speaking communicative environment and get acquainted with lexical units of level $\mathrm{C} 1$ and higher. Apart from training materials, some test items are selected from such special-purpose network resources as the website Cambridge English Write and Improve.

In special subjects, students do tasks that are as close as possible to those of international language exams. For example, in the class in Foreign Language Academic Discourse they are supposed to follow written models and employ corresponding vocabulary when doing IELTS written tasks based on visuals. In subjects that involve mastering professional English, students work with fragments of the official Cambridge Teaching Knowledge Test (TKT) preparation materials.

The second exam preparation area involves performing tasks tailored to fit the examination format in a non-examination context, for example, the one centred around the content of TV series and fiction. The Home Reading manual based on the novel The Cuckoo's Calling by Robert Galbraith and its BBC film adaptation Strike, contains tasks from all sections of the Cambridge Advanced exam (e.g. CAE essays and speaking tasks on the problems raised in the book, as well as Listening, Reading and Use of English tasks) [19]. Cambridge Advanced speaking tasks are practised with the help of mind maps and pictures designed and/or selected for problem questions discussion and related to the plot of books and series. For example, students are encouraged to discuss the following problem question and key ideas based on I. McEwan's novel Atonement: How might these actions help people to atone for their crimes? (Consider the following: serving in the army, working for charity, going on a pilgrimage to a sacred place, working in a hospital, donating money to charity).

If such tasks are performed on a regular basis and interlocutors are constantly rotated, students do not experience stress at a real exam.

Another important area of integrating international exam preparation activities into the academic process is students' self-study, which is organised through wide use of modern elearning tools. They allow students to make their own choices regarding the time and manner of performing tasks and 'shuffle' them.

The Moodle LMS, a distance learning management system, is widely used by our foreign language learners. Various tools available on this platform help automate a large number of processes, simplify the language teacher's work, increase the efficiency of student's selfstudy, reduce the preparation time, as well as ensure fruitful communication between the teacher and the student. Many types of test tasks in the LMS can be completed both online and offline, which makes it possible to personalize the educational process and fill it with additional content.

The experiment as such was carried out in 2020-2021. Before starting the work, a survey was organized to determine the attitude of the students and graduates of the Foreign Languages Faculty to international language exams.

The survey, which was completed by 235 people ( 157 students and 78 graduates of the Foreign Languages Faculty), revealed the following. $88.1 \%$ of the respondents believe that 
graduates of the Foreign Languages Faculty should receive an independent assessment of the level of proficiency in a foreign language according to international standards, while $11.9 \%$ do not think so. At the same time, only $25.1 \%$ of the respondents had any previous experience of sitting an international exam. In response to the question, "Are you planning to take an international exam in the future?" (Fig. 1) 3\% of those surveyed expressed an intention to take the exam in the upcoming session, $10.6 \%$ were planning to sit the exam in the autumn of 2021 while $73.2 \%$ intended to take the exam as the need arose. At the same time, $13.2 \%$ of the respondents did not express any slightest interest in international exams. It is important to note that a number of respondents indicated that they were going to take several different exams.

\section{Are you planning to take any sandardised language test?}

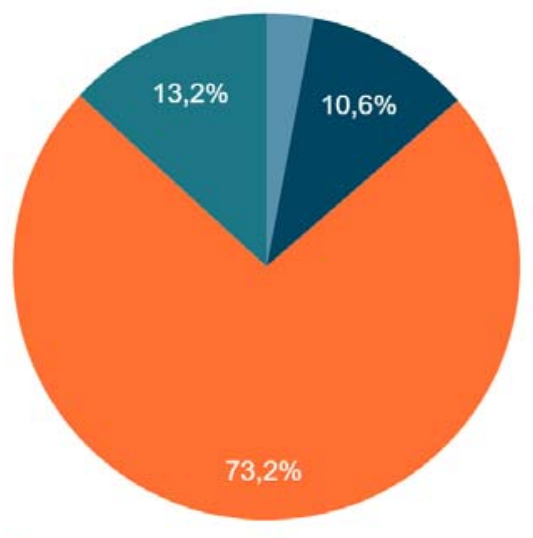

Yes, in May 2021

Yes, in autumn of 2021

Yes, when I need it for work, study or any other reason No

Fig. 1. Survey results.

CAE, IELTS and TOEFL are the most requested exams, with $32.3 \%, 20 \%$ and $12.8 \%$ respondents, respectively. Other exams on the 'to-take' list include FCE, CPE, as well as TKT, CELTA and DELTA, PTE, French and German certification exams.

Experimental training involved introducing the designed materials and classroom management techniques in teaching the language subjects in the senior years at the Foreign Languages Faculty. In total, 8 classes of $3^{\mathrm{d}}$ to $5^{\text {th }}$ year students took part in it.

In the entrance and final testing aimed to determine the level of proficiency in language skills, the participants were offered authentic CAE tasks that were further assessed according to the Cambridge Assessment criteria. Below are the results of testing conducted in a group of 66 participants in the 2020-2021 academic years. 


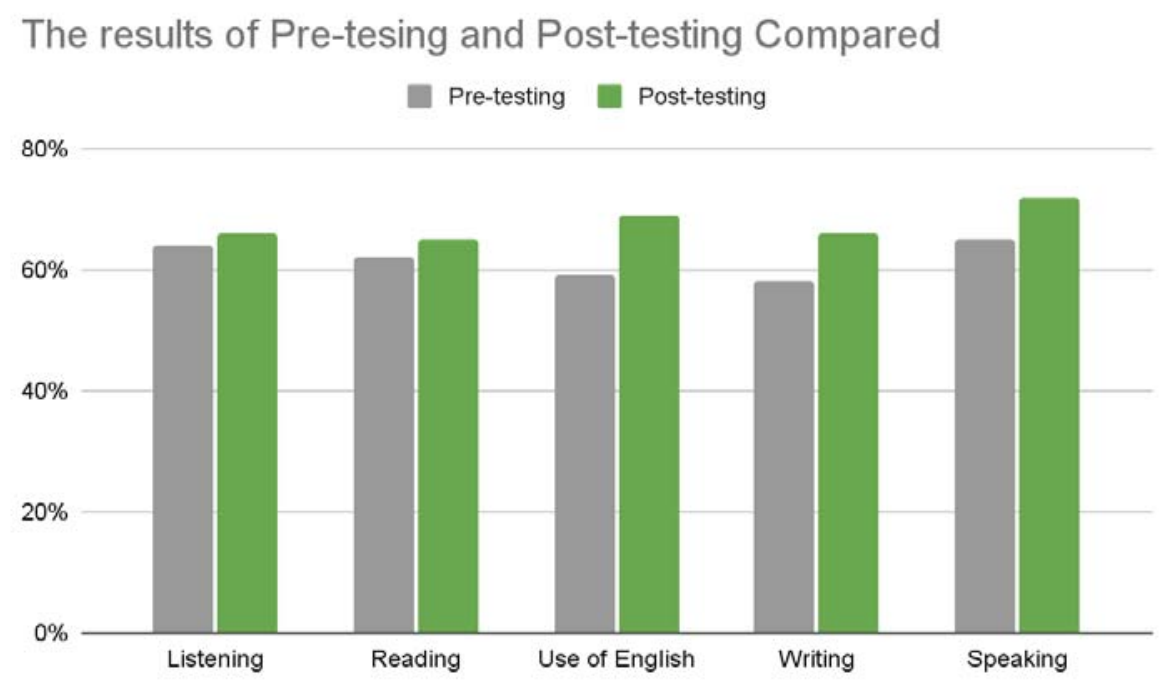

Fig. 2. Comparison of the results of the entrance and final testing.

According to the diagram (Fig. 2), there is a slightly slower progress in Reading and Listening than in the other exam skills as tasks from these sections are considered the most difficult and, thus, require systematic, targeted preparation. Doing "Use of English" tasks on a regular basis within the self-study might significantly improve the results on condition that the language skills are already well developed. A high degree of regularity in practising Speaking tasks would eliminate the following problems encountered by the learners during the entrance testing: the number of hesitation pauses, lack of coherence and unwillingness to interact in a dialogue.

\section{Discussion}

In our opinion, the academic progress that the students of the Foreign Languages Faculty of $\mathrm{KSU}$ demonstrated in doing the Cambridge tests proves that integration of international exam preparation into the academic process bears fruit. Such approach to managing the in-class and self-study activities motivates students and lays the foundation for further independent preparation of graduates for the international exam.

The research results were reflected in a number of publications, final graduation papers and manuals published by the teachers, as well as in the increased interest in international exams among students and graduates of the Foreign Languages Faculty of Kursk State University.

\section{Conclusion}

The proposed model of integrating the preparation for international exams into the curricula of the Foreign Languages Faculty has been proved effective. It ensures systemic development of foreign language skills, regular consistent practice of completing typical examination tasks and reduction of the stress level in a real exam situation as well. The students' entrance and final testing showed significant progress in the development of the assessed skills. 
According to the study, it is necessary to consistently continue integrating the preparation for international exams into teaching foreign languages and special subjects at the Foreign Languages Faculties in all three areas mentioned above.

\section{References}

1. Federalnyi gosudarstvennyi obrazovatelnyi standart vysshego obrazovaniya bakalavriat po napravleniyu podgotovki 45.03.02 Lingvistika. Utverzhden prikazom Ministerstva nauki i vysshego obrazovaniya Rossiiskoi Federatsii Zaregistrirovano v Minyuste Rossii 25 avgusta 2020 g. № 59448 [Federal State Educational Standard of Higher Education - Bachelor's Degree majoring in 45.03.02 Linguistics. Approved by order of the Ministry of Science and Higher Education of the Russian Federation Registered with the Ministry of Justice of Russia on August 25, 2020 No. 59448]. Accessed on: July 19, 2021. [Online]. Available: http://fgosvo.ru/uploadfiles/FGOS\%20VO\%203++/Bak/450302_B_3_31082020.pdf

2. H. Richards, C. Conway, A. Roskvist, S. Harvey, The Lang. Learn. J. 41(2), 231-246 (2013). https://doi.org/10.1080/09571736.2012.707676

3. J. Ch.Alderson, T.Brunfaut, L.Harding, Asses. Edu.: Princ., Pol. Prac. 24(3), 379-387 (2017). https://doi.org/10.1080/0969594X.2017.1331201

4. P. Winke, H. Lim, Lang. Asses. Quart. 14(4), 380-397 (2017). https://doi.org/10.1080/15434303.2017.1399396

5. M.O. Hamid, N.T.H. Hoang, A. Kirkpatrick, Curr. Iss. Lang. Plan. 20(3), 226-244 (2019). https://doi.org/10.1080/14664208.2018.1495371

6. B.O’Sullivan, K. Dunn, V. Berry, Asses. Edu.: Princ., Pol. Prac. 28(1), 13-36 (2021). https://doi.org/10.1080/0969594X.2019.1637820

7. G. Levitskaya, E. Levitskaya, J. Lang. Edu. 2(2), 33-42 (2016). https://doi.org/10.17323/2411-7390-2016-2-2-33-42

8. V.V. Vonog, J. Sib. Fed. Univ. Hum. \& Soc. Sci. 10(10), 1630-1636 (2017). https://doi.org/10.17516/1997-1370-0160

9. M. Kovalenko, J. Lang. and Edu. 4(1), 63-78 (2018). https://doi.org/10.17323/24117390-2018-4-1-63-78

10. E. Smirnova, T. Permyakova, M. Sheveleva, J. Lang. and Edu. 3(4), 27-35 (2017). https://doi.org/10.17323/2411-7390-2017-3-4-27-35

11. N. Staroverova, O. Petrova, V. Mosc. St. Ling. Univ. 645, 93-100 (2012).

12. A. Humphry-Baker, Babylonia J. Lang. Teach. \& Learn. 3 (2002). Accessed: July 27, 2021. [Online]. Available: http://babylonia.ch/en/archive/anni-precedenti/2002/number3-02/preparing-students-for-international-examinations/

13. S.A. Zainal Abidin, A. Jamil, Lang. Teach. 5(3) (2015), https://doi.org/10.1177/2158244015597725

14. K. Sadeghi, T. Rahmati, Asses. Writing 34, 50-61 (2017). https://doi.org/10.1016/j.asw.2017.09.003

15. R. Ivanova, A. Ivanov, M. Lyashenko, J. Lang. and Edu. 3(2), $45-54$ (2017). https://doi.org/10.17323/2411-7390-2017-3-2-45-54

16. A. Derakhshan, F. Shakki, Innov. Teach. Dif. Instr. to Cater for Stud. Diver. 8(4) (2018). https://doi.org/10.1177/2158244018809408

17. S.A. Zhemchugova, L.N. Evseeva, E.L. Safronenkova, Pedag. Prob. Theory and Prac. 5(1), 33-40 (2020). https://doi.org/10.30853/pedagogy.2020.1.6 
18. S. Saif, J. Ma, L. May, L. Cheng, Asses. Edu.: Princ., Pol. \& Prac. 28(1), $37-57$ (2021). https://doi.org/10.1080/0969594X.2019.1700211

19. A.E. Bobneva, D.V. Fedorova, Solve a Crime with Cormoran Strike (Publishing house of KSU, Kursk, 2020) 